УДК 323:316.4

https://doi.org/10.34142/24130060.2020.21.2.02

\title{
ЕВРИСТИЧНИЙ ПОТЕНЦАЛ КОНЦЕПТУ «ГЛИБИННА ДЕРЖАВА» В ПОЛІТОЛОГІЧНІЙ АНАЛІТИЦІ
}

\author{
О. В. Воронянський \\ Харківський національний технічний університет сільського господарства \\ імені Петра Василенка
}

\begin{abstract}
Стаття присвячена розгляду конщепту «глибинна держава», який на протязі останніх років активно впроваджується в плошину політичного аналізу. Розглянуто основні підходи до визначення сутності глибинної держави в американській та вітчизняній політичній аналітиці, а також проблему наукової новизни даного терміну та аналітичної концепції, побудованої на його базі. Показано, щзо в рамках економічної системи, яка орієнтована на отримання індивідуального прибутку, внаслідок монополізації відбувається системна переорієнтація механізму держави від виконання загальносочіальних функцій на закріплення тіньових інститутів, які начілені на забезпечення привілейованого доступу до влади і джерел ресурсного забезпечення для обмеженого кола ресурсозабезпечених груп. Це супроводжується відсіканням від доступу до інституційного впливу на прийняття владних рішень для основної маси громадян.
\end{abstract}

Ключові слова: глибинна держава, владний перерозподіл ресурсів, політична інституціоналізація.

\section{ЭВРИСТИЧЕСКИЙ ПОТЕНЦИАЛ КОНЦЕПТА «ГЛУБИННОЕ ГОСУДАРСТВО» В ПОЛИТОЛОГИЧЕСКОЙ АНАЛИТИКЕ}

\section{А. В. Воронянский}

Статья посвящена рассмотрению конщепта «глубинное государство», который в течение последних лет активно внедряется в плоскость политического анализа. Рассмотрены основные подходы к определению сущности глубинного государства в американской и отечественной политической аналитике, а также проблема научной новизнь данного термина и аналитической концепции, построенной на его базе. Показано, что в рамках экономической системы, ориентированной на получение индивидуальной прибыли, вследствие монополизации, происходит системная переориентация механизма государства с выполнения общесочиальных функиий на закрепление теневых институтов, которые начелены на обеспечение привилегированного доступа к власти и источникам ресурсного обеспечения для ограниченного круга групп. Это сопровождается ликвидацией доступа к институциональному влиянию на принятие властных решений для основной массы граждан.

Ключевые слова: глубинное государство, властное перераспределение ресурсов, политическая институцчионализащия.

(C) О. В. Воронянський, 2020 


\section{HEURISTIC POTENTIAL OF THE DEEP STATE CONCEPT IN POLITICAL SCIENTIFIC ANALYSIS}

\section{O. Voronianskyi}

The article is devoted to the consideration of the concept of «deep state», which in recent years has been actively implemented in the field of political analysis. The main approaches to defining the essence of the deep state in American and domestic political analysis, as well as the problem of scientific novelty of this term and the analytical concept built on its basis are considered.

The proposed theoretical concept, indeed, to some extent adequately describes the existing system of power-distribution relations, which form the basis of political institutions and, in particular - the institutions of state power. However, it does not provide fundamental novelty for political analysis, as it actually repeats the conclusions of Marxism and neo-institutionalism.

It is shown that within the economic system, which is focused on individual income, due to monopolization there is a systematic reorientation of the state mechanism from general social functions to consolidate shadow institutions aimed at providing privileged access to power and sources of resources for a limited number of resource groups. This is accompanied by a cut-off from access to institutional influence on government decision-making for the majority of citizens.

In fact, the shadow state is a real state, and what is presented as a «public state» is only a front sign for those members of society who do not face political reality. If the need to use the ideology of democracy as a basis for legitimizing the power of a privileged minority is lost, there is no need to divide state institutions into official («front») and shadow (hidden from the majority of the population). Therefore, the term «deep state», in our opinion, may have a rather narrow scope to describe the system of shadow, informal institutions of power and their generated practices of making and implementing government decisions in a society with pronounced limited access to sources of resources for the majority politically full citizens at a time when this restriction has not yet created sufficient conditions for the systematic consolidation of the privileges of the ruling minority in the form of estate barriers and the elimination of civil rights for the majority of society.

Key words: deep state, power redistribution of resources, political institutionalization.

Постановка проблеми. Вважається, що дефініція «глибинна держава» (deep state) в широкий політологічний дискурс перейшла 3 області конспірології після того, як у 2017 р. президент Сполучених Штатів Дональд Трамп зробив публічну заяву про існування цієї держави в США. У трампівській інтерпретації дане поняття означає тіньове об’єднання фінансової олігархії, керівництва спецслужб і частини високопоставлених чиновників державного апарату, які становлять спротив рішенням обраного народом президента.

Аналіз актуальних досліджень. Сьогодні указану дефініцію в основу описання політичних систем своїх країн використовують знакові аналітики США, держав Європейського Союзу, Росії та Туреччини, активно 
впроваджується вона і у вітчизняну практику політологічного аналізу. Проте як точна сфера застосування самого терміну, так і його аналітичне значення, обумовлене науковим методологічним принципом, відомим під назвою «бритви Оккама», залишається недостатньо визначеним.

Метою даної наукової розвідки (статті) є короткий огляд основних підходів до визначення концепту глибинної держави в американській та вітчизняній літературі, а також принципове визначення його місця в системі наукового аналізу з точки зору структурно-функціонального підходу.

Виклад основного матеріалу. У лексиці американських політиків i журналістів термін «глибинна держава» став широко використовуватися ще 3 2014 р. У широкий обіг його запровадив колишній співробітник апарату республіканської партії в Конгресі США 3 майже тридцятирічним стажем Майк Лофгрен. Він застосував цей термін для опису тіньового міжпартійного консенсусу «державних чиновників i представників верхнього рівня фінансистів і промисловців, які ефективно управляють США, не питаючи про це виборців» (Lofgren, 2011). Підставою для такого висновку стали не тільки особисті спостереження Майка Лофгрена, але і вивчення ним досліджень професорів Прінстонського та Північно-Західного університетів Мартіна Гіленса й Бенджаміна Пейджа. Вони опубліковані в доповіді «Тестування теорій американської політики: еліти, зацікавлені групи, і пересічні громадяни», де проаналізовано дані за період з 1981 по 2002 рр.. Результатом цих досліджень став висновок про те, що, незважаючи на наявність демократичних інститутів, США є скоріше олігархією, ніж демократією, а влада спирається майже виключно на «багатих людей і зацікавлені групи, які представляють бізнес» (Gilens \& Page, 2014). Тому в сфері податкової, соціальної та торговельної урядова політика майже повністю відповідає уподобаннями еліт і практично ігнорує погляди пересічних громадян.

Згідно висновкам М. Лофгрена (2011), глибинна держава черпає силу 3 національної безпеки і розвідки, перетворюючись на царство, де секретність $\epsilon$ джерелом влади. Звідси основу глибинної держави складають саме 
спецслужби, створені високопоставленими особами в рядах розвідувальних організацій, військових і судових інститутів, а також організованих злочинних груп. Надбудову глибинної держави становлять союзи, створені топ-менеджерами фінансового та промислового секторів 3 певними представниками уряду та чиновниками середньої ланки. Так, почесний професор Каліфорнійського університету Пітер Дейл Скотт підводить під дане визначенням підрядників військових замовлень, бенефіціарів нафтовидобувних компаній і фінансових інститутів (Savchenko, 2020). Жанін Пірро до механізму глибинної держави відносить також пул медіа-холдингів, які цілеспрямовано захищають інтереси олігархів і афільованих 3 ними політиків. Саме об’єднання таких угрупувань, а не офіційні органи влади, на думку прибічників концепції глибинної держави, реально керують США, приймаючи відповідні рішення i нав'язуючи свої плани так званим «офіційним особам», яких «демократично обирає народ» (Pirro, 2018).

Поняття «глибинна держава» було сприйнято в американській політичній науці в основному позитивно, оскільки допомагає описувати існуючу в цій країні політичну реальність. Певною мірою воно доповнило поняття «істеблішмент», яке означає сукупність людей, що займають ключові позиції в соціально-політичній системі, являються опорою існуючого суспільного ладу i формують громадську думку, а також сукупність соціальних інститутів, за допомогою яких ці люди підтримують існуючий соціальний порядок (Denysenko, 2013). При цьому дослідниками відзначається, що на відміну від істеблішменту, глибинна держава не підтримує національну безпеку, а підриває ii, порушуючи стабільність політичної системи. Так, професор Джейсон Ройс Ліндсі в своєму дослідженні «Приховування від держави», стверджує, що термін «глибинна держава» - це корисний термін, який допомагає зрозуміти ряд негативних аспектів інституту національної безпеки в розвинених країнах (2013). Низка опозиційних американських авторів протягом останніх декількох років використовують поняття «глибинна держава» для дезавуювання ідеологеми 
«США - оплот і гарант світової демократії», вказуючи на немічність американських демократично обраних осіб перед глибинною державою (Denysenko, 2015). Однак у більшості випадків в американській літературі політологічного спрямування дане поняття описується 3 позицій конспірологічної «теорії змови», а не з позицій інституційного і структурнофункціонального аналізу соціальних систем.

Показовою у цьому плані $є$ концепція, підтримувана відомим американським автором Томасом Хорном, який пов’язує діяльність глибинної держави 3 активністю широко розповсюджених у середовищі фінансової та політичної еліт штатів різноманітних таємних товариств - від окультистів до масонів. На думку американських конспірологів, американська еліта і таємні товариства, сформувавши Тіньовий уряд у Вашингтоні, прагнуть до світової влади заради встановлення «Остаточного Світового Порядку» (Horn, 2017).

Саме наративна близькість концепції глибинної держави до «теорії змови», яка давно й неодноразово продемонструвала свою наукову неспроможність, дозволяє дослідникам неоліберального спрямування висміювати іiі як конспірологічний міф.

В Україні концепт глибинної держави активно просувається в область політичної аналітики через Інститут майбутнього, що входить до сфери впливу Офісу ефективного регулювання (який у свою чергу створювався «західними партнерами» України як ії тіньовий уряд і став інкубатором для Кабінету міністрів Олексія Гончарука). Експерт цього інституту Сергій Дацюк вказує, що у вітчизняному політичному просторі остаточно оформилися дві держави:

- глибинна держава, яка має три рівні: глибинний президент, глибинний парламент і глибинне громадянське суспільство;

- публічна держава з публічним президентом, публічним парламентом і публічним суспільством (Hvilya, 2019a). 
При цьому глибинна держава існує в раціональному просторі, оскільки реальною мірою всіх відносин в цьому просторі $\epsilon$ ступінь доступу до ресурсу. У публічній же державі простір ірраціональний, оскільки через публічні інститути громадянин не може отримати доступ до ресурсу. Тому громадянин підтримує відносини саме 3 глибинною державою через корупційний консенсус, обмінюючи свої фінансові ресурси на доступ до інших ресурсів. Звідси, за С. Дацюком, глибинне громадянське суспільство складається з тих громадян, які мають відповідні ресурси (Hvilya, 2019b).

3 указаного корупційного консенсусу виріс олігархічний консенсус, який i став основою глибинної держави. При цьому глибинна держава змушена витрачати частину отримуваної нею владної ренти на утримання публічної держави, оскільки остання є ресурсом, на якому вона паразитує. Олігархи та корупція в такій моделі інституційних відносин є системним наслідком монополізованої вертикально-інтегрованої економіки. Нинішня монополізована вертикально-інтегрована економіка в принципі не передбачає від’єднання олігархів від держави.

Згідно поданої С. Дацюком концепції, саме сучасна потоково-мережева економіка, яка заміщує собою стару радянську економіку, створює свої органи - Глибинний Президент, Глибинний Парламент, Глибинний Уряд. Легалізація ж потоково-мережевої економіки буде означати й відповідну зміну структури державного управління (Hvilya, 2019c).

Пропонована теоретична концепція, дійсно, певною мірою досить адекватно описує існуючу систему владно-розподільчих відносин, які формують основу політичних інститутів i, зокрема, - інститутів державної влади.

Необхідно зазначити, що вказаний конструкт не $є$ чимось принципово новим для політичної аналітики. Ще Карл Маркс визначав сучасну йому державу як комітет по управлінню справами великої буржуазії. Володимир Ленін у праці «Імперіалізм як вища стадія капіталізму» в 1916 р. відзначав, що утворення фінансового капіталу і фінансово-промислових груп неминуче 
тягне за собою зрощення цих груп i держави. За радянських часів таке зрощення називалося державно-монополістичним капіталізмом. У самих США ще в 1956 р. Чарльз Райт Міллс у своїй книзі «Владна еліта» писав, що на середину XX ст. влада в Америці виявилася зосередженою в трьох основних підрозділах: військово-промисловому комплексі, Уолл-стріт і Пентагоні (Mills, 2007).

У рамках мейнстімної в сучасній західній політичній соціології на протязі вже декількох десятиліть неоінституційної системи аналізу також визначається, що конфігурацію політичних інститутів, зокрема держави, формує через «пакт еліт» саме баланс сил ресурсозабезпечених суб'єктів соціальних відносин. При цьому реальна демократія «для всіх» не може існувати за умовчанням, а насправді держава забезпечує так звану «демократію обмеженого доступу» (Nort, 1997), відсікаючи від реального впливу на прийняття державно-владних рішень основну частину суспільства.

На нашу думку, теоретичний інструментарій неоінституціоналізму цілком дозволяє зробити висновок про те, що фактично будь-як державна організація в умовах орієнтованої на отримання індивідуального прибутку економічної системи, починає втрачати свої загальносоціальні функції і перетворюється на механізм забезпечення владного статусу певного кола привілейованих груп.

Разом із тим, було б перебільшенням вважати, що концепція глибинної держави не надає нічого нового для політичної науки. 3 одного боку, на відміну від марксистського аналізу сутності буржуазної класової держави, та неоінституціоналізму, ця концепція не орієнтована на розкриття структурнофункціонального зв’язку феномену відчуження і концентрації політичної влади з орієнтованою на індивідуальний прибуток економічною системою. Однак, із іншого - вона привертає увагу суспільної думки до існування цього феномену, показуючи системну невідповідність декларованої ідеологеми загальнонародної «національної держави» сутності реально існуючого 
закритого для переважної більшості громадян інституційно закріпленого порядку доступу до влади і джерел ресурсів.

Є також принципова відмінність американського розуміння глибинної держави від вітчизняного. Так, М. Лофгрен спеціально зазначає, що в даний час глибинна держава створена в кожній країні так званого «золотого мільярду». Вона об’єднана в глобальну владну структуру, що нагадує підводну частину айсберга, видиму частину якого становлять офіційні ключові політики, з якими зазвичай пов’язують основні геополітичні процеси в усьому світі (Lofgren, 2011). Тому й боротьба з глибинною державою з боку груп американських підприємців, фронтменом яких виступає Дональд Трамп, є боротьбою 3 транснаціональними фінансово-монополістичними угрупуваннями, які паразитують на ресурсній базі США та інших країн.

Концепт же глибинної держави, пропонований через Інститут майбутнього українським аналітикам і представникам апарату державного управління, під глибинною державою розуміє лише картельну змову вітчизняних олігархічних груп, боротися з якими може лише незалежна від останніх система, що формується транснаціональними установами - ЄС, МВФ, міжнародні суди (такі як Гаазький трибунал, Страсбурзький суд, Високий суд Лондону тощо) (Hvilya, 2019b). Таким чином, вказаний концепт фактично створений як інструмент ідеологічного впливу транснаціональних корпорацій для легітимації інституцій із зовнішнім управлінням, які б забезпечили демонтаж владної конструкції, зведеної об’єднанням вітчизняних олігархічних груп для захисту своєї ресурсної бази від вторгнення іноземних рейдерів.

Ще один вітчизняний концепт глибинної держави, запропонований Олександром Савченком, розглядає іï як інституційну патріотичну стійкість ключових інститутів державної влади, що базується на сталому персоналі цих інститутів. Оскільки сталий патріотичний (на думку автора концепції) персонал є сильнішим, ніж постійно змінюване під впливом політичних змін 
керівництво, тому воно вимушено грати за правилами глибинної держави (Savchenko, 2020).

Такий підхід повністю ігнорує основані на результатах багаторічних комплексних наукових досліджень загальновизнані в політичній науці висновки про формування груп інтересів у корпорації державних чиновників на основі привласнення владної ренти. Він є скоріше, пропагандистським курйозом, а не спробою оформлення наукової концепції.

Висновки і перспективи подальших досліджень. У цілому можна зробити висновок, що не зважаючи на різноманітність підходів до визначення та застосування терміну «глибинна держава», загальним у них можна вважати те, що даним терміном позначається система або системна практика прийняття державно-владних рішень, яка існує паралельно 3 офіційною державною системою і діє в обхід конституційно оформлених політичних інститутів.

Дефініція «глибинна держава» певної мірою відображає політичну практику постіндустріального суспільства, в якому заміна конкуренції на олігополію в економічній сфері поряд з відмиранням масового робітничого руху тягне за собою заміну «фасадної демократії» держави національного типу з іï ідеологемою загального добробуту на «демократію обмеженого доступу» 3 притаманними останній демонтажем соціальних функцій держави і концентрацією влади в руках космополітичного олігархату. На нашу думку, при дотриманні певних методологічних засад дана дефініція здатна відображати багаторазово описану і фактологічно підтверджену в науковій літературі практику підготовки і прийняття суспільно значущих владних рішень не сформованими через процедуру виборів представницькими органами влади, а неофіційними політичними інститутами, які об’єднують інтереси ресурсозабезпечених бізнес-груп та топ-чиновників не виборної вертикалі виконавчої влади та спецслужб. Проте спроба оформлення конструкту глибинної держави у вигляді концепції в порівнянні 3 марксизмом та неоінституціоналізмом не надає нічого принципово нового 
для наукового аналізу самого механізму і процесів відчуження основної маси громадян від доступу до центрів влади та розподілу ресурсів у суспільстві.

Крім того, феномен, описуваний терміном «глибинна держава», являє собою системний наслідок загального процесу концентрації капіталу (яка прямо пропорційна концентрації влади), внаслідок чого буржуазна держава, за своєю сутністю орієнтована на вузьке коло привілейованих ресурсозабезпечених угруповань, через нормативно-правову систему та владні установи завжди підтримує для цих груп порядок привілейованого доступу до ресурсів за рахунок обмеження доступу до них для основної маси населення. Звідси зрозуміло, що в рамках економічної системи, заснованої на засадах індивідуального прибутку, державно-владні рішення системно будуть прийматися не лише в інтересах ресурсозабезпеченої меншості, але й в обхід формальних демократичних процедур (до тих пір, поки самі ці процедури будуть необхідними для легітимації влади меншості).

Фактично, тіньова держава i $є$ справжньою державою, а те, що подається під назвою «публічна держава» - лише фасадна вивіска для тих членів суспільства, які не стикаються з політичною реальністю. У разі втрати необхідності використання ідеологеми демократії як основи для легітимації влади привілейованої меншини, відпадає й необхідність у розділенні державно-владних інститутів на офіційні («фасадні») й тіньові (приховані від більшості населення). Тому термін «глибинна держава», на нашу думку, може мати досить вузьку сферу застосування для описання системи тіньових, неформальних інститутів влади та генерованих ними практик прийняття й реалізації державно-владних рішень у суспільстві 3 яскраво вираженим обмеженим доступом до джерел ресурсного забезпечення для основної маси політично повноправних громадян у період, коли це обмеження ще не створило достатніх умов для системного закріплення привілеїв правлячої меншини у вигляді станових перегородок і ліквідації громадянських прав для більшості суспільства. 


\section{ЛІТЕРАТУРА}

1. Денисенко, I. Д., 2013. Сучасна теорія конфлікту: проблеми експлікації, демаркації, класифікації. Українській соиіум, 3(46), с. 16-26.

2. Денисенко, І. Д., 2015. Теорія соціального простору: евристичний потенціал щодо соціально-політичних досліджень. Сучасне суспільство: політичні науки, соиіологічні науки, культурологічні науки, 2(10), с. 2737.

3. Миллс, Р., 2007. Властвующая элита. Москва: Директмедиа Паблишинг.

4. Норт, Д. 1997. Институты, институциональные изменения и функционирование экономики. Москва: Фонд экономической книги Начала.

5. Савченко, О., 2020. Таємниці влади. Хто насправді керує Україною? [online] Доступно: https://savchenko.co.ua/tayemnicivladi-xto-naspravdi-keruye-ukraïnoyu/ [Дата звернення 25 Вересень 2020].

6. Хвиля, 2019а. Методичка для Президента Украины. Часть 1. Глубинное государство. [online] (Последнее обновление 15 Апрель 2019) Доступно: https://hvylya.net/interview/society2/metodich ka-dlja-prezidenta-ukrainy-chast-1-glubinnoegosudarstvo.html [Дата обращения 15 Октябрь 2020].

7. Хвиля, 2019b. Методичка для Президента Украины. Часть 2. Соотномение глубинного и публичного. [online] (Последнее обновление 24 Апрель 2019) Доступно:

https:/hvylya.net/interview/politics2/metodich ka-dlja-prezidenta-ukrainy-chast-2-

sootnoshenie-glubinnogo-i-publichnogo.html [Дата обращения 15 октябрь 2020].

8. Хвиля, 2019с. Методичка для Президента Украины-3. Глубинная экономика и глубинное правительство. [online] (Последнее обновление 24 Май 2019) Доступно:

https://hvylya.net/interview/politics2/metodich ka-dlja-prezidenta-ukrainy-3-glubinnajajekonomika-i-glubinnoe-pravitelstvo.html [Дата обращения 15 Октябрь 2020].

9. Gilens, M. \& Page, B. I., 2014. Testing Theories of American Politics: Elites, Interest Groups, and Average Citizens. Perspectives on Politics, [online] 12(3), pp. 564-581. Available at: https://www.cambridge.org/core/services/aopcambridge-

core/content/view/62327F513959D0A304D48

\section{REFERENCES}

1. Denysenko, I. D., 2013. Suchasna teoriia konfliktu: problemy eksplikatsii, demarkatsii, klasyfikatsii. Ukrains'kij sotsium, 3(46), s. 1626.

2. Denysenko, I. D., 2015. Teoriia sotsial'noho prostoru: evrystychnyj potentsial schodo sotsial'no-politychnykh doslidzhen'. Suchasne suspil'stvo: politychni nauky, sotsiolohichni nauky, kul'turolohichni nauky, 2(10), s. 27-37.

3. Mills, R., 2007. Vlastvuyuschaya elita. Moskva: Direktmedia Pablishing.

4. Nort, D. 1997. Institutyi, institutsionalnyie izmeneniya i funktsionirovanie ekonomiki. Moskva: Fond ekonomicheskoy knigi Nachala.

5. Savchenko, O., 2020. Taiemnytsi vlady. Khto naspravdi keruie Ukrainoiu? [online] Dostupno: https://savchenko.co.ua/tayemnicivladi-xto-naspravdi-keruye-ukrainoyu/ [Data zvernennia 25 Veresen' 2020].

6. Hvilya, 2019a. Metodichka dlya Prezidenta Ukrainyi. Chast 1. Glubinnoe gosudarstvo. [online] (Poslednee obnovlenie 15 Aprel 2019) Dostupno:

https://hvylya.net/interview/society2/metodich ka-dlja-prezidenta-ukrainy-chast-1-glubinnoegosudarstvo.html [Data obrascheniya 15 Oktyabr 2020].

7. Hvilya, 2019b. Metodichka dlya Prezidenta Ukrainyi. Chast 2. Sootnoshenie glubinnogo i publichnogo. [online] (Poslednee obnovlenie 24 Aprel 2019) Dostupno: https://hvylya.net/interview/politics2/metodich ka-dlja-prezidenta-ukrainy-chast-2sootnoshenie-glubinnogo-i-publichnogo.html [Data obrascheniya 15 Oktyabr 2020].

8. Hvilya, 2019c. Metodichka dlya Prezidenta Ukrainyi-3. Glubinnaya ekonomika i glubinnoe pravitelstvo. [online] (Poslednee obnovlenie 24 may 2019) Dostupno: https://hvylya.net/interview/politics2/metodich ka-dlja-prezidenta-ukrainy-3-glubinnajajekonomika-i-glubinnoe-pravitelstvo.html [Data obrascheniya 15 Oktyabr 2020].

9. Gilens, M. \& Page, B. I., 2014. Testing Theories of American Politics: Elites, Interest Groups, and Average Citizens. Perspectives on Politics, [online] 12(3), pp. 564-581. Available at:

https://www.cambridge.org/core/services/aopcambridge-

core/content/view/62327F513959D0A304D48 93B382B992B/S1537592714001595a.pdf/testi ng-theories-of-american-politics-elites-interestgroups-and-average-citizens.pdf [Accessed 25 September 2020] 
93B382B992B/S1537592714001595a.pdf/testi ng-theories-of-american-politics-elitesinterest-groups-and-average-citizens.pdf [Accessed 25 September 2020]

10. Horn, T. R., 2017. Saboteurs: How Secret, Deep State Occultists Are Manipulating American Society Through A WashingtonBased Shadow Government In Quest Of The Final World. Tennessee, Memphis: Defender Publishing.

11. Lindsey, J. R., 2013. The Concealment of the State. Bloomsbury Academic.

12. Lofgren, M., 2011. Goodbye to All That: Reflections of a GOP Operative Who Left the Cult. [online] (Last updated 03 September 2011) Available at: https://truthout.org/articles/goodbye-to-allthat-reflections-of-a-gop-operative-who-leftthe-cult/\#\%5b3 [Accessed 25 September 2020]

13. Pirro, J., 2018. Liars, Leakers, and Liberals: The Case Against the Anti-Trump Conspiracy. New York.: CenterStreet.

14. Scott, Peter Dale, 2014. The State, the Deep State, and the Wall Street Overworld. The Asia-Pacific Journal, 12 (5), pp. 98-112.
10. Horn, T. R., 2017. Saboteurs: How Secret, Deep State Occultists Are Manipulating American Society Through A WashingtonBased Shadow Government In Quest Of The Final World. Tennessee, Memphis: Defender Publishing.

11. Lindsey, J. R., 2013. The Concealment of the State. Bloomsbury Academic.

12. Lofgren, M., 2011. Goodbye to All That: Reflections of a GOP Operative Who Left the Cult. [online] (Last updated 03 September 2011) Available at: https://truthout.org/articles/goodbye-to-all-thatreflections-of-a-gop-operative-who-left-thecult/\#\%5b3 [Accessed 25 September 2020]

13. Pirro, J., 2018. Liars, Leakers, and Liberals: The Case Against the Anti-Trump Conspiracy. New York.: CenterStreet.

14. Scott, Peter Dale, 2014. The State, the Deep State, and the Wall Street Overworld. The Asia-Pacific Journal, 12 (5), pp. 98-112.

\section{Інформація про автора}

Воронянський Олександр Володимирович - кандидат історичних наук, професор, професор кафедри ЮНЕСКО «Філософія людського спілкування» та соціальногуманітарних дисциплін Харківського національного технічного університету сільського господарства імені Петра Василенка; e-mail: voronyansky@gmail.com; ORCID: http://orcid.org/0000-0003-4926-8887.

Стаття надійшла до редакції: 26.10.2020 р. $\quad$ Прийнята до друку: 16.11.2020 p. 